though their contractility remains unimpaired. By washing with $0.05 M$ sodium bicarbonate - glycerol, the activity was lost entirely in five days at $-20^{\circ} \mathrm{C}$. It could be restored by incubation for $30 \mathrm{~min}$. in dialysed muscle extract. This factor $X$ appeared repeatedly in the fraction obtained between 50 per cent and 70 per cent saturated ammonium sulphate precipitation, and withstood exhaustive dialysis.' We concluded that $X$ is probably a protein-enzyme for which creatine phosphate is a necessary substrate.

After long bicarbonate-glycerol washing there was a steady decrease in the speed, though not the maximum tension, of contraction; the speed could be restored by addition of small amounts of cysteine, or of acid-boiled extract which does not contain $X$-factor.

The sharp $p H$ dependence of the $X$-creatine phosphate system has special significance for the mechanism of the initiation of the contraction cycle, in view of the $p \mathrm{H}$ difference 5.8-7.4 estimated by Boyle and Conway ${ }^{7}$ which is maintained between the inside and outside of the intact fibre by the membrane. We note here that the work of Marsh $^{8}$ and Bendall ${ }^{9}$ which reports factors with similar activity makes no reference to $p \mathrm{H}$ dependence. They appear to agree, however, on the role of divalent ions; in this respect there is also agreement with the work of Bozler ${ }^{10}$.

$$
\text { M. C. GOODALL }
$$

ANDREW G. SzENT-GYöRGYI

Institute for Muscle Research,

Marine Biological Laboratory,

Woods Hole, Massachusetts. Jan. 5.

'Szent-Györgyi, A., "Chemistry of Muscular Contraction" (Academic Press, New York, 2nd edit., 1951).

${ }^{3}$ Goodall, M. C. (unpublished work).

${ }^{3}$ Szent-Györgyi, A. G., Enzymologia, 14, 246 (1950). Portzehl, H., Z. Naturforschung, $7 \mathrm{~b}, 1$ (1952).

${ }^{4}$ Hill, A. V., Proc. Roy. Soc., B, 141, 104 (1953).

${ }^{5}$ Varga, L., Enzymologia, 14, 196 (1950).

${ }^{6}$ Ennor, A. M., and Stocken, I. A., Biochem. J., 48, 190 (1948).

'Boyle, P. J., and Conway, E. J., J. Physiol., 100, 1 (1941).

${ }^{8}$ Marsh, B. B., Nature, 167, 1065 (1951); Biochim. et Biophys. Acta, 9, 247 (1952)

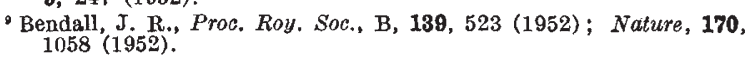

${ }^{10}$ Bozler, E., Amer. J. Physiol., 168, 760 (1952).

\section{Cryptolæmus montrouzieri Mulsant in South India}

IN Nature of March 1, 1952, Puttarudriah et al., in reporting the occurrence of Cryptolomus montrouzieri near Bangalore, refer to the lack of information on its introduction into India beyond a statement on an index card in the U.S. Department of Agriculture that an unsuccessful attempt was made in 1898.

In the course of some research into the history of the United Planters' Association of Southern India, which attains its diamond jubilee this year, it has been found that this attempt to introduce Cryptolomus into southern India is well documented, although the documents have been concealed in appendixes to the Proceedings of the Association and are therefore not readily available.

At the annual general meeting of the Association in 1896, Mr. H. O. Newport, a planter of the Lower Pulneys (Madura District), raised the question of biological control as a means of dealing with the newly introduced Coccus viridis Gr., which was attacking coffee and causing serious alarm, and referred specifically to the work of Koebele in Hawaii. Mr. Newport, an amateur entomologist, had already observed indigenous coccinellids predatory on the Coccus, and he pressed the Association to raise funds to organize the introduction of Cryptolcemus. In the following year, the Association passed the following resolution : "That this Association do allot Rs. 2,000 from the Reserve Fund to be added to any other sums raised for the purpose of introducing Coccinellidæ into Southern India with the object of combating scale pests. . . . That the Planting Member of Council be instructed to ascertain to what extent the Government of Fort St. George will afford financial assistance. ... That in the event of a sufficient sum being raised, a qualified person, preferably Mr. Newport, be despatched to Australia and elsewhere to collect and bring back the Coccinellidae". Rs. 6,050 was subscribed, of which Rs. 1,000 came from the Madras Government, and Mr. Newport left India on January 30,1898 , and arrived back towards the end of June with a consignment of some 4,300 adult beetles comprising 2,540 Orcus australasice Boisd., 1,500 Cryptoloemus montrouzieri Mulsant and 246 Rhizobius ventralis Erichs. which had been conveyed in ice chests. Subsequent events can best be described in Newport's own words. "Within an hour or so of my arrival there [at his coffee estate in the Lower Pulneys] on the 20th of June, I opened out five of the cases, containing some 2,500 of the lady birds of all three varieties. These I opened out on a cloth on the coffee trees, some in the sunlight and some in the shade. . . . The lady birds, when I turned them out, were mostly clinging to the moss which $I$ had put in the boxes, and they looked healthy enough, only one or two here and there looked seedy. Most of them were full bodied and soft, their legs and antennæ I could move freely with a needle and those that I squeezed were full and moist inside. I could, I regret to say, however, get them to show no signs of life. . . . I had no better success with the second half than I had with the first half consignment".

In the following year, Newport left south India to take up an appointment with the Government of Queensland as instructor in coffee cultivation, so that the matter was not followed up in the area of liberation. There would seem a possibility that eggs or pupæ among the packing could have given rise to viable adults, or some of the apparently dead adults may have survived and escaped observation.

The notation on Dr. Clausen's card files 'Howard 1898' undoubtedly arises from the fact that the Secretary of the United Planters' Association of Southern India forwarded a copy of "Planting Opinion" containing Newport's report on October 5, 1898 , and this was acknowledged by Howard on November 7 of the same year.

The combination of depredations by the coccid and $a_{0}$ heavy fall in coffee prices led to a considerable decline in coffee growing in the Lower Pulneys, and the local district planters association was wound up in 1899. This, together with Mr. Newport's departure, effectively extinguished interest in this attempted introduction ; but it seems that it was more successful than its originator could have dared to hope. The total expenditure incurred on this project was Rs. 4,773 , or a little more than $£ 300$ at the 1898 stabilized rate of exchange.

Scientific Department,

W. WILSON MAYNE

Kanan Devan Hills Produce Co., Ltd.,

Munnar P.O., Travancore, S. India. 